\title{
A Comparative Study of Human Embryo's Developmental Stages of Sawwak, Addalak, Mudgha and Organogenesis (In the Context of Islam and Embryology)
}

\author{
${ }^{*}$ Dr. Nosheen Zaheer \\ "Dr. Syed Hamid Farooq Bukhari \\ ".*ainab Sadiq
}

\section{ABSTRACT:}

The process of creation of man is not a simple process it is rather the formation and organization of the most complicated and well-designed evolutionary systems. These complex creational procedures are written in Islam (Quran and Hadith) that indicates the most decisive stages with specific terminologies like nutaf imshaj, alaqa, sawwak, addalak, mudgha, and organogenesis. This paper aims to utilize the comparative approach to compare the Islamic information regarding creation of man to embryological studies to find the similarities and differences if present. This com-parison will be limited to the areas of Sawwak, addalak, mudgha and organogenesis.

Keywords: Embryology, Sawwak, Addlak, Mudgha and Organogenesis. Introduction:

Human being, the most complicated and advanced evolutionary creature, have attained the status of crown of creation on the upper rungs of Vertebrates. The advanced body systems of man are linked with their complex creative stages through which he passes inside their mother wombs. These multifaceted creational stages are identified in the Quranic text as signs and marks for each distinct developmental stage, the information of which is decoded in detail by scientific inventions. Quran identifies the pre-natal developmental stages in surah 23 as:

"Then we changed the drop (nutfah) into leech like structure (alaqah). Then we changed the leech like structure into chewed like substance (mudgha)."1

The above mentioned Quranic verse describes sequential developmental stages from the union of reproductive substance. The color and viscosity of these reproduc-tive substances (viscous white male while less denser yellowish female substance) coincide with the latest scientific information (viscosity of semen is $3.92 \mathrm{cp}$. while female's straw color substance with viscosity that ranges between 1.3 to $1.8 \mathrm{cp}$ ). The union of these substances called nutfa (zygote formation). This nutfa in Quranic terminologies before attaining the stage of Alaqah will firmly fix itself to a specific place called qararim maqeem for a specific period called qadrim maloom while in scientific explanation this place of rest is apical protrusions in the uterine wall named as pinopodes. The attachment of nutfah will lead to the stage of Alaqah which is defined differently by different Muslims scholars. Some transited the world alaqah as congealed

*Dean of Humanities SBK Women's University, Quetta. / Email: nosheenirma@gmail.com

" Lecturer, Department of Islamic Studies, University of Gujrat.

"*" Lecturer, COMSATS Institute of Information Technology, Islamabad. 
blood; other equates it as a hanging body and some scholars associate it with leech like structure. The embryological evaluation also reveals the fact that the penetration and attachment of the embryo to uterine wall to attain nourishment from the mother's blood resemble it with leech. In the third week in the chronic cavity, the blastocyst is attached through a stalk, justifies the second Quranic meaning of hanging or suspended body. Similarly, in the third week appearance of Blood Island in embryo takes place which is the precursor of blood vessels and cells. Therefore, the embryo appearance is quite similar to congealed blood. ${ }^{2}$ The morphology and physiology of the human embryo at this stage justifies the profundity of Quranic word alaqah that further elaborate the whole process during which embryo changes its form from nutfah to alaqah. The further growth of the embryo after alaqah that involves not only the physical changes rather encompasses the internal modification is mentioned in the Quranic verses with sawak and adaalak. The holy Quran states that:"Who (Allah) created you, made you even and straight (sawwak) and then modified (addalak) you". ${ }^{3}$

In the above mentioned ayah the term Sawwak means even and straight. ${ }^{4}$ Here even and straight means fashioning the embryo in great proportion that each of its components is placed perfectly. This Quranic information coincides with embry-ological studies that mark the flattening, and almost rounding and gradually elongation of embryonic disc, with a broader cephalic (head) and narrow caudal end. ${ }^{5}$ That further leads to the establishing of anterio-posterior (head to tail), dorso-ventral (from back to belly) and left-right of body axes ${ }^{6}$ before and during the mudgha stage. Thus this stage marked by the orderly arrangement of embryo that enables its body to retain the shape with distinct border head and narrow caudal end. The next stage according to Quran is Addalak which literally have many meaning but in the context of human development, it means changes and modification. ${ }^{7}$ Logically, in the context of Quranic verse when the stage of smoothness is followed by the stage of modification it clearly reveals the fact that smoothness is replaced by unevenness which in the terminology of embryology is the formation of thickness called streak. The embryo in its 15th to 16th days has a narrow groove can be noticed that is slightly bulging on each side. ${ }^{8}$ This primitive streak can be differentiated into three firstly primitive grooves, secondly primitive node and thirdly primitive pit. ${ }^{9}$ Thus the appearance of a streak and narrow groove on embryo will transform it into an uneven and bumpy look that foreshadows the upcoming changes in embryo in the form of organogenesis.

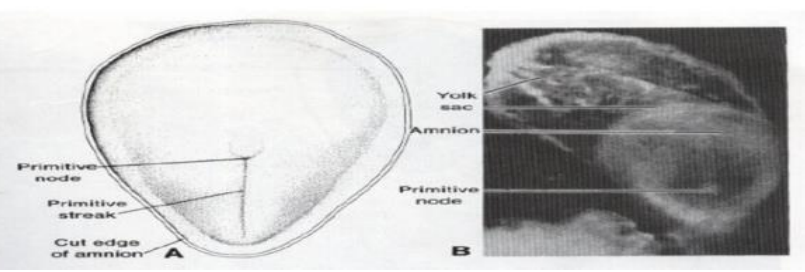

Figure 1. A. Showing dorsal aspect of an 18-days embryo. The embryo has pear-shaped appearance and shows the primitive streak and node at its caudal end. B. photograph of the 18-day human embryo, dorsal view. 
The above mentioned process of modification is summarized in the verse of the Holy Quran as,

"Hum nee insane ko do rangy bond see bnaya. Usai platai rahe aur usai kar deya suune wala aur deekhnai wala." 10

Here (do range bond) in embryology is combination of ovum and sperm called fertilization, while "platai" means changing the order and also migrations of cells that give rise to three germs layers (three veils of Darkness) and "suune wala aur deekhne wala" marks the stage of organogenesis when embryo is bestowed by faculties of hearing and seeing by Allah. The stage of modification and cell migration will equip the embryo with three germ layers the precursors of fetal body which in the terminology of the holy Quran is "Three Veils of Darkness."

\section{Three Veils of Darkness:}

In Surah 39 Almighty Allah Says:

"He it is who creates you in stages, one after another, in three veils of darkness"11

There is a misunderstanding among the Muslims and Non- Muslim scholars regarding the scientific interpretation of this verse. As Muslim scholars are equating these three veils of darkness as abdominal wall, uterine wall and the placenta with chorineamniotic membrane. ${ }^{12}$ While the non-Muslins are raising objections on the Muslim interpretation of this verse that why should they take three veils of darkness in the Muslim interpretation context. They have queries that why one could not equate these veils to uterine wall, chorion, endometrium and amnioch-orionic? According to them, the choice regarding these veils is arbitrary.

The above mentioned discussion demands the researcher to focus the terminology Khalaqa (created you) used in Quranic verses. If Almighty Allah uses the word "protected you" then it includes all those membranes which are providing protection to embryo like amnion, chorion etc. But the word "created" clearly explains the lamina or veils that are the precursors of embryo. Here the term "three veils" represent the three veneers (layers) or lamina and "Darkness" means the whole process is hidden or in the unclear state. But if someone equating the three layers with extraembryonic membranes like amnion then it is worth mentioning that during developmental stage this cavity also experience changes and its size changes gradually. And in the 11th week embryo also start contributing the amniotic fluid by urinating in the amniotic cavity. Thus the average change in the size of the cavity can be seen in different weeks, in 10 weeks it size is $30 \mathrm{ml}$, in week 20 it is $350 \mathrm{ml}$ and in week 37 it is $700-1000 \mathrm{ml} .{ }^{13}$ The above mentioned size of the amniotic cavity excludes it and other cavities from the discussion of three veils of darkness as its size cannot be justified in the context of Quranic language "in Darkness" (obscure or not clear). Therefore the three veils according to Quranic information accords with a scientific revelation that the whole embryo is embedded in hidden form in a single layer. When this layer undergoing the process of differentiation and development it gives rise to three germ layers. ${ }^{14}$ 
Thus, the epiblast the source of these germ layers ecto, endo and mesoderm differentiate into three layers through the process of gastrulation that will further give rise to all tissues and organs. ${ }^{15}$ This whole process of differentiation, tissue and organ formation is not explored fully through scientific discoveries and could be called "in darkness" in Quranic language. Thus the three veils seem to be three germ layer the source of creation of embryo, its tissues and organs the formation of which further transform the appearance of embryo into chewed like substance or mudgha.

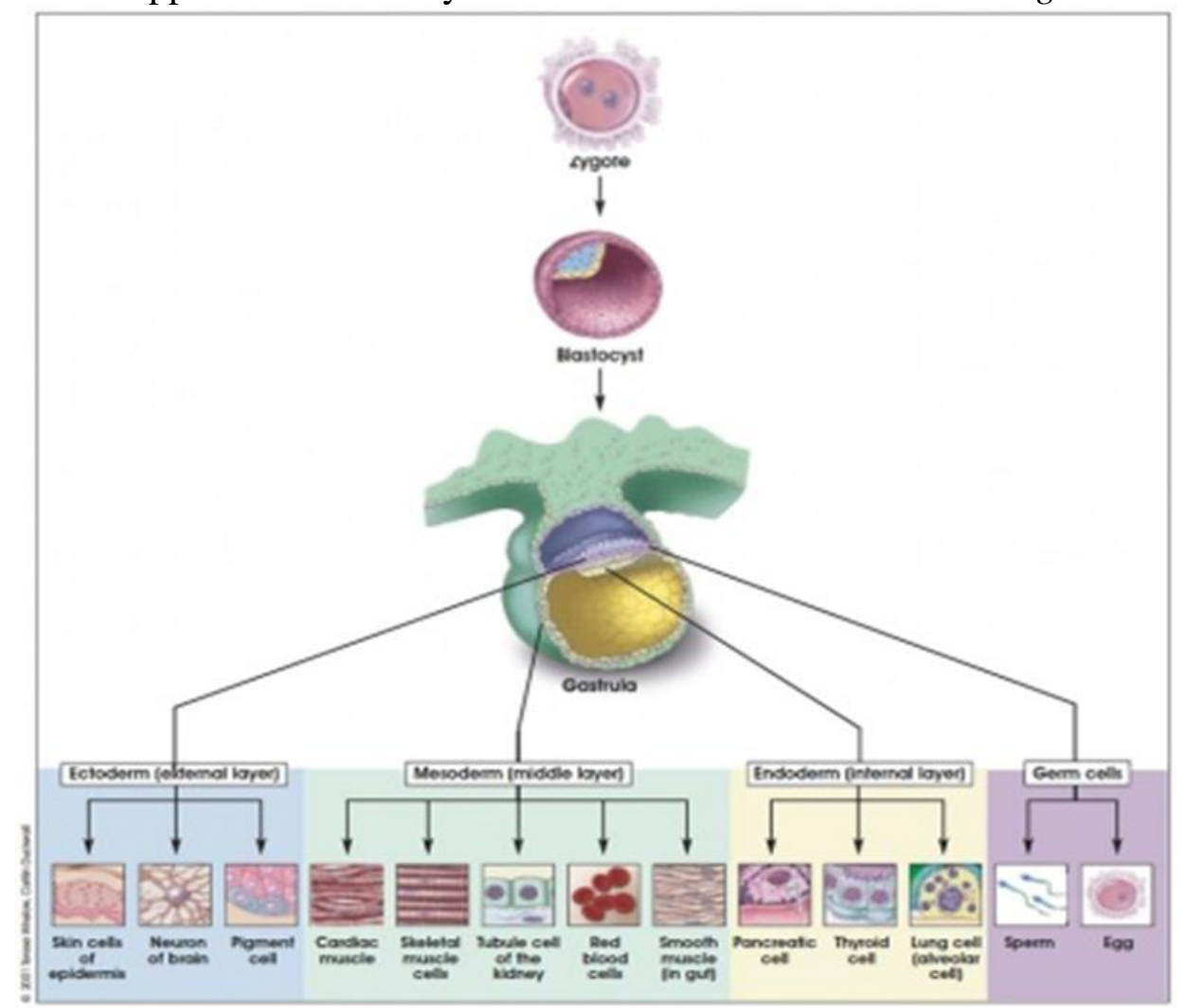

Figure 2. Showing a schematic explanation from zygote formation to gastrulation of human embryo.

\section{Mudgha (Chewed Like Substance)}

In Surah 23 Allah almighty says:

"Then we changed the leech like structure into chewed like substance (mudgha)."16 The term mudgha literally means chewed substance. ${ }^{17}$

Embryological studies reveal the stage that exhibits the chewed marks (mudgha), in scientific language these chewing imprints are termed as somites. The appearance of these imprints can be noticed in the third week when paraxial mesoderm experiences the differentiation process that results in the formation of cuboidal bodies termed as somites. These somites appear triangular in transfer section and it formed distinct elevation on the embryo. ${ }^{18}$ The discovery of these somites was credited to Professor Keith Moore who during his research found that when a piece of seal having similar 
shape and size of fetus are chewed it resulted in the chewing marks on the seal. The comparison of these chewed marks was then compared with the somites and Pro. Keith was astonished that these teeth imprints resembled the somites. ${ }^{19}$

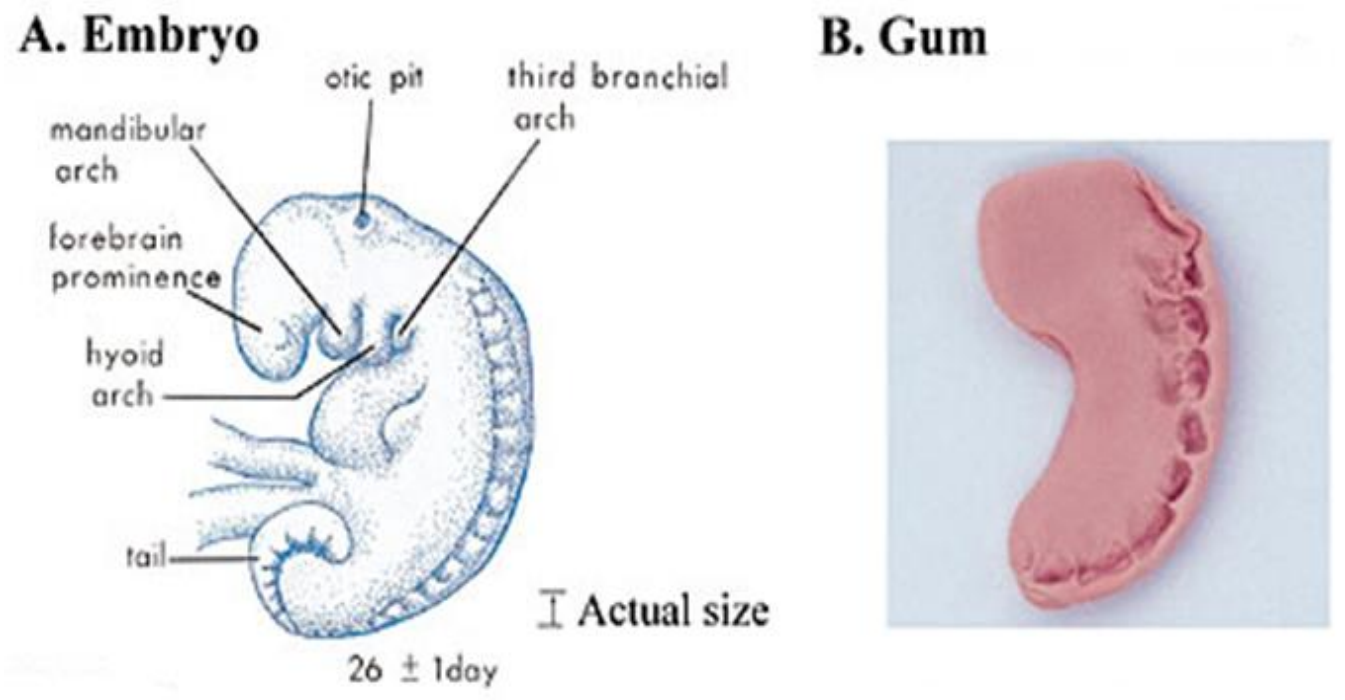

Figure 3. When comparing the appearance of an embryo at the mudgha stage with a piece of gum that has been chewed, we find similarity between the two.

Prof. Keith Moore admitted in the forward of his book "The Developing Human" that: "I was astonished by the accuracy of the statements that they were recorded in the 7th Century $\mathrm{AD}$ before the science of embryo was established. Although I was aware of the glorious history of Muslims scientists in the 10th Century AD and to some of their contribution to medicine, I knew nothing about the religious facts and beliefs contained in the Quran and Sunnah. It is important for Islamic and other students to understand the meaning of the Quranic statements about human development, based on current scientific knowledge." 20

Mudgha pointers the next stage of organogenesis and Quran linked these two phases as:

"Then out of chewed-liked substance (mudgha) partly formed and partly un-formed." 21

The two words mentioned in above mentioned verse are worth mentioning is

1. Partly formed (partly differentiating)

2. Partly un-formed (partly undifferentiating)

Here the term partly differentiating means the stage where embryo acquires some characteristic externally that gives embryo the shape of human embryo. This differentiation involves increase in head size and formation of limbs, face, ears and nose. ${ }^{22}$ While the term undifferentiated is totally applied to the gonadal system of embryo because the gonads of both sexes are identical in appearance until the seventh week. The differentiation of these gonads involves the switching on of number of genes at specific time. Male embryo genetically carries Y chro-mosome having SRY 
gene for a testis-determining factor (TDF). The absence of a Y chromosome or the presence of two $\mathrm{X}$ chromosomes results in the formation of an ovary. The process of testis formation starts from the seventh week while the ovaries cannot be identifiable until above the 10th weeks. ${ }^{23}$ Therefore this partly formed and partly unformed stage further leads the embryo to its final destination where partly formed organs attain completion and the partly unformed organs reach the stage of formation and then completed through the process called organogenesis.

\section{Organogenesis:}

Organogenesis is the process of production and also development of the embryonic organs. In Quran Almighty says:

"Verily we created man from a drop of mingled sperm, I order to try him: so we gave him (the gifts) of hearing and sight."24

The countercheck of Quranic information regarding sight and hearing can be done through the information provided in the Adahith Mubraka pointing out the exact time for this stage. In a hadith Holy Prophet explained that the time when the eyes of embryo are shaped by angel Gabriel on the commands of Allah as,

"When forty-two nights have passed over the drop Allah sends an angel to it who shapes it and makes it ears, eyes, skin, flesh and bones. Then he says, O! Lord, is it male or female? And your Lord decides and the angel records it." 25

The above stated hadith describes the sequence of parallel development of ears, eyes, skin, flesh and bones after 42 days. Likely, the embryology firstly, explains the formation of eyelids during the sixth week (42) days from the mesenchyme that is derived from the neural crest and from the two folds of skin, growing over the cornea. ${ }^{26}$ Secondly, the most form of congenital deafness is caused by genetic factors but the role of environmental factors in deciding the fate of embryo's hearing cannot be ignored. This is the reason that Rubella virus, affecting the embryo in the seventh week may cause severe damage to the origin of corti. ${ }^{27}$ Thirdly, the first hyaline cartilage development is also marked by six weeks that will foreshadow the bones of the embryos. The skeleton of the embryo to six weeks is cartilaginous. These cartilaginous skeleton latter form long bones that will facilitate the formation of large muscle mass in each limb bud. Fourthly, in the six week myogenic precursors cells migrate into limb bud that will later differentiate into myoblast the precursor of the muscle cells. ${ }^{28}$

In the light of the above stated discussion, it could be concluded that the Islamic information regarding the creation of man inside the mother womb is very precisely explained the sequential stages from sawwak, addalak, mudgha and organogenesis. The comparison of this information with embryological studies reveals that the sources of these information's are totally different in their natures from each other. As the Quran is not a book of embryology it is rather a book of sign for those who wants to attain hadayah from their lord while the embryological studies are scientific studies of man's creation. But besides these differences, the information regarding the man's creation inside his mother womb is when compared through the comparative 
approach. The finding reveals that the Quranic signs of man creation not only coincide with the embryological studies in the morphological details of each stage rather these both agree in the minutest details on genetic and chronological level.

\section{References:}

\section{${ }^{1}$ Al-Quran, Surah al-Mu'minun 23:14}

'Zaheer, Nosheen. "Human Embryo's Developmental Stages of Fertilization, Implantation and 'Alaqah (A Comparative Study of Islam and Embryology)." Peshawar Islamicus, 2016: pp.9-13

${ }^{3}$ Al-Quran, Surah Al Infitar 82:7-8

${ }^{4}$ Ibn e Omar Al-Zamkhshari, Abul Qasim Jar Allah Mahmoud. Al-kashshaf an Haqiqa Al-Tanzeel wa Uyun Al-Aqaweel. Beirut: Dar Al-Kitab Al-arabi, 1407, p.716

${ }^{5}$ W. Sadler T. Langmnan's Medical Embryology. Maryland: Lippincot Williams \& Wilkins, 2004, p.77 ${ }^{6}$ ibid, p.72

${ }^{7}$ Ibn e El-Razzak, Abu Al-Faidh Al-Sayed Mohamma Ibn Mohammad Ibn Mohammad. Taj Al-'Aroos Min Jawahir Al-Qamoos. Cairo, 1306, p.8

${ }^{8}$ W. Sadler T. Langmnan's Medical Embryology. Maryland: Lippincot Williams \& Wilkins, 2004, p.65

${ }^{9}$ Ronald, W. Dudek and Fix, Jmaes D. Board Review Series Embryology. Edited by 2nd. William and Wilkins, 2006, p.29

${ }^{10}$ Al-Quran, Surah Al Insan 76:1-2

${ }^{11}$ Al-Quran, Surah Al Zumar 39:6

${ }^{12}$ Abadi, maulana Abdul Majeed Sahab Durya. Tafseer e Majdi. Lahore: Taj Company , 1994, p.919

${ }^{13}$ Persuade, Moore. Before we are Born Essentials of Embryology and Birth Defects. China: Saundera, 2003, p.106

${ }^{14}$ Kaltoff, Kalus. Analysis of Biological Development. New York: McGraw-Hill, 2001, p.246

${ }^{15}$ W.Sadler T. Langmnan's Medical Embryology. Maryland: Lippincot Williams \& Wilkins, 2004, p.65

${ }^{16}$ Al-Quran, Surah al-Mu'minun 23:14

${ }^{17}$ Al-Jawhary, Abu Nasr Ismail Ibn e Hammad. Al-Siahah, Taj al--Lughah wa Sihah Al-Arabiah. Beirut: Dar Al-'Ilm Lil-Malayeen, 1979, p.4

${ }^{18}$ Persuade, Moore. Before we are Born Essentials of Embryology and Birth Defects. China: 2003, p.55

${ }^{19}$ Naik, Zakir. The Quran and Modern Science Compatible or Incompatible. Lahore: Beacon Books, 2007, p.51

${ }^{20}$ Moore, Keith L. The Developing Human: With Islamic Additions. Jeddah: Commission for Scientific Miracles of Quran and Sunnah, 1982, p.10

${ }^{21}$ Al-Quran, Surah Al Hajj 22:5

${ }^{22}$ W.Sadler T.Langmnan's Medical Embryology. Maryland: Lippincot Williams \& Wilkins, 2004, p107

${ }^{23}$ Persuade, Moore. Before we are Born Essentials of Embryology and Birth Defects. China:2003, p247

${ }^{24}$ Al-Quran, Surah Al Mursalat 76:2

${ }^{25}$ Muslim, Imam. Sahih Muslim. Edited by Mika'il al-Almany. Translated by abd-al hamid Siddiqi. 2009, book 33, Hadith 6393, p.1583

${ }^{26}$ Persuade, Moore. Before we are Born Essentials of Embryology and Birth Defects. China:2003, p380

${ }^{27}$ W.Sadler T.Langmnan's Medical Embryology. Maryland: Lippincot Williams \& Wilkins, 2004, p411

${ }^{28}$ Persaud, Moore. Before we are BornEssentials of Embryology and Birth Defects. China: Saundera, 2003, pp.331-332

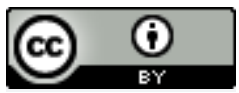

This work is licensed under a Creative Commons Attribution 4.0 International License. 